УДК 665.24.032

\title{
ЕКСПЛУАТАЦІЙНІ ВЛАСТИВОСТІ ДРУКАРСЬКОГО АПАРАТУ ФЛЕКСОДРУКАРСЬКИХ АРКУШЕВИХ МАШИН
}

\author{
( Б. О. Черня, к.т.н., доцент, О. П. Шостачук, аспірант, \\ НТУУ «КПІ», Київ, Україна
}

\section{Определены и систематизированы эксплуатационные свой- ства печатных аппаратов листовых флексографских машин, которые влияют на качество печати на гофрокартоне.}

In this article are identified and classified performance characteristics of printing sheet flexo machines that has influence for the print quality on corrugated board.

\section{Постановка проблеми}

На сьогодні більше 90 \% всіх видів товарної продукції потребує паковання. Тому розвиток індустрії виготовлення паковання і тари має динамічний характер. В розвинутих країнах їх виробництво складає приблизно 2 \% від валового національного продукту, а його світовий обсяг на середину 2010 року оцінюється приблизно 480-550 млрд. дол. США [1] (за даними WPO, Світової організації з паковання та Британського об'єднання PSRA). Паковання виготовляється з різноманітних матеріалів: паперу, картону, плівок, пластмаси, металу чи скла. Картонні матеріали займають до 40 \% від загальних обсягів світового ринку паковання. Поліграфічному оформленню паковання приділяється велика увага, оскільки наряду 3 інформаційною функцією про продукт воно $є$ маркетинговим інструментом. Відомо, що для нанесення зображення на тару з гофрокартону (ГК) застосовують переважно флексографічний спосіб друку. Зростання питомої ваги тари з гоф- рокартону і доля флексодруку на ринку паковання показана на рис. 1.

На рис. 2 представлена технологічна схема флексографічного апарату для друку на гофрокартоні. Еластична друкарська фотополімерна форма (ФПФ) монтується на формний циліндр (ФЦ) за допомогою двосторонньої липкої стрічки, яку приклеюють на його робочу поверхню. У процесі друку здійснюється контакт форми 3 робочою поверхнею анілоксового валу (AB), комірки якого заповнюються рідкою фарбою під тиском чи за допомогою дукторного валу. Анілоксовий вал при обертанні рівномірно і дозовано переносить фарбу на друкарські елементи форми. 3 форми фарба переноситься на поверхню листа 3 гофрокартону. Він транспортується між формним і друкарським циліндрами (ДЦ), що постійно обертаються, а їх робочі поверхні виставлені з робочим зазором. Це забезпечує транспортування заготовки визначеної товщини та створення технологічно необхідного дру- 
карського тиску. Друкарський циліндр має функцію протидії. Поверхня ГК має високу всотувальну здатність, тому застосовують екологічно чисті водорозчинні фарби. До особливостей технологічного процесу відносять використання друкарської форми в якості носія зображення і одночасно декеля. Еластичні фотополімерні форми і низька в'язкість фарб дозволяють друкувати з низькими значеннями друкарського тиску, відповідно, без пошкодження структури гофрокартону.

На сьогодні змінюються акценти до якості поліграфічного оформлення тари з гофрокартону. Якщо раніше основними елементами зображення були плашки та штрихові ілюстрації, то сьогодні необхідно забезпечити оформлення ящика растровими зображеннями. Створення умов оптимального переносу фарби на матеріал для отримання відбитка є задачею механіки друкарського контакту для будьякого конкретного способу друку [2]. При вивченні цього пи- тання розглядаються явища у зоні друкарського контакту, пов'язані $з$ деформаціями, тиском при друку та навантаженнями, які обумовлені особливостями технологічного процесу, технологічною схемою побудови друкарського апарату та його конструктивним оформленням. Для виявлення і розв'язання вказаних задач для випадку друку на ГК флексографічним способом необхідно виявити вплив на якість друку особливостей технологічної схеми процесу, фізико-механічних властивостей ФПФ і ГК, побудови конструкції друкарського апарату (ДА) і функціональних параметрів його складових частин. Ці чинники розкриваються через свої експлуатаційні властивості [3]. 3 врахуванням багатофакторності цих складових дослідження повинні мати системний підхід.

\section{Аналіз попередніх досліджень}

Огляд джерел і наукових праць дозволяють зробити наступний висновок. Системні досліджен-

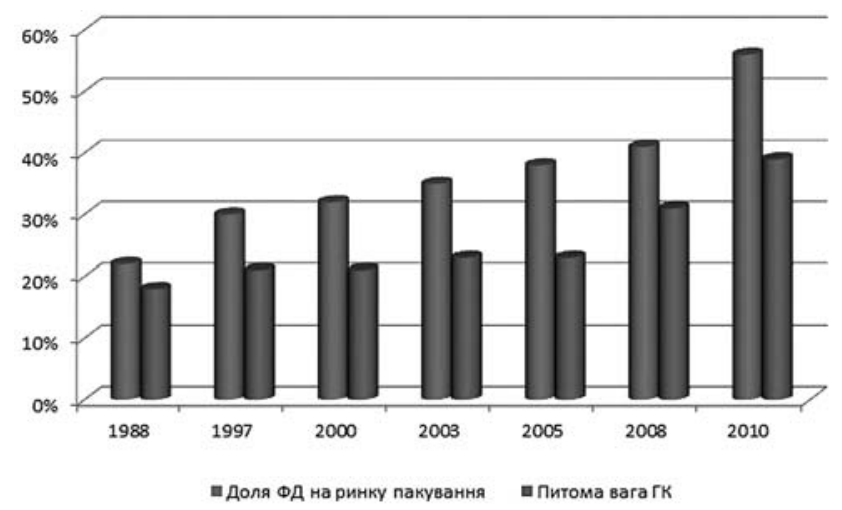

Рис. 1. Зростання питомої ваги тари з гофрокартону і доля флексодруку на ринку паковання 
ня щодо якісного друкування на гофрокартоні і залежності його в комплексі від особливостей технологічного процесу і фізико-механічних властивостей його складових, а також від будови конструкції флексодрукарського апарату - не проводились. Ряд праць присвячено розгляду фізико-механічних властивостей фотополімерних пластин та форм [4-9]. Їх вивчення основному пов'язані зі зміною іх фізико-механічних властивостей в залежності від режимів обробки на етапі виготовлення, а також при дисторсії. Розгляд залежності якості вихідної продукції і дефектів при друкуванні розглядається в основному через фарби та параметри лініатури анілоксового валу, а вплив властивостей ГК розглядається в основному через стан його поверхні, тобто властивостей верхнього лайнера $[10,11]$. В [9] тиск при друці визначається значеннями 0,1 ..0,5 МПа, мінімально допустимі навантаження деформації стиску форми: 0,02...0,2 мм.

\section{Мета роботи}

Мета роботи полягає у систематизації показників якості експлуатаційних властивостей складових технологічного процесу флексодруку на ГК і друкарського апарата, що впливають на механіку друкарського контакту. Це дозволить в подальших дослідженнях цілеспрямовано виявити їх вплив на якість друку і оптимізувати їх дію.

\section{Результати проведених досліджень}

1. При визначенні експлуатаційних властивостей чинників впливу на якість друку на гофрокартоні будемо використовувати трактовку понять і визначень ГОСТ 15467-79. Відповідно до його положень властивість - це об'єктивна особливість продукції, що проявляється при її створенні, експлуатації або споживанні і розкривається і оцінюється за допомогою показників якості. Ïх сукупність розглядають як якість продукції. Стосовно технологічного обладнання для поліграфічних виробів та паковання якість визначають його придатністю виробляти продукцію заданого тиражу і якості при мінімальних витратах. Вона розкривається через техніко-експлуатаційні властивості, які вказують на можливості ефективного використання обладнання, визначення його технічного стану, ефективної експлуатації при за-

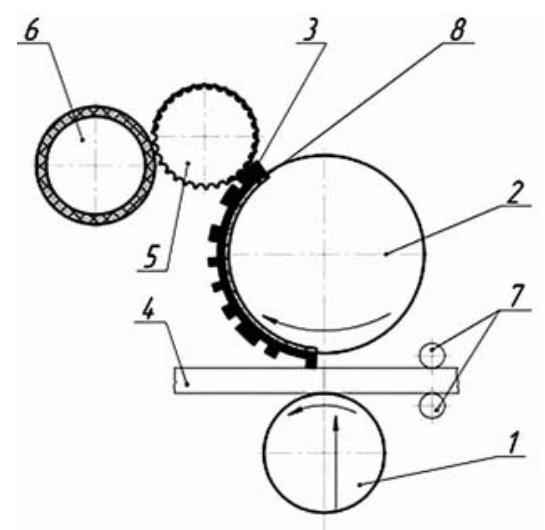

Рис. 2. Технологічна схема флексографічного способу друку на ГК: 1 - друкарський циліндр;

2 - формний циліндр; 3 - фотополімерна друкарська форма;

4 - гофрокартон; 5 - анілоксовий вал; 6 - дукторний вал; 7 - транспортуючі валики; 8 - монтажна стрічка 


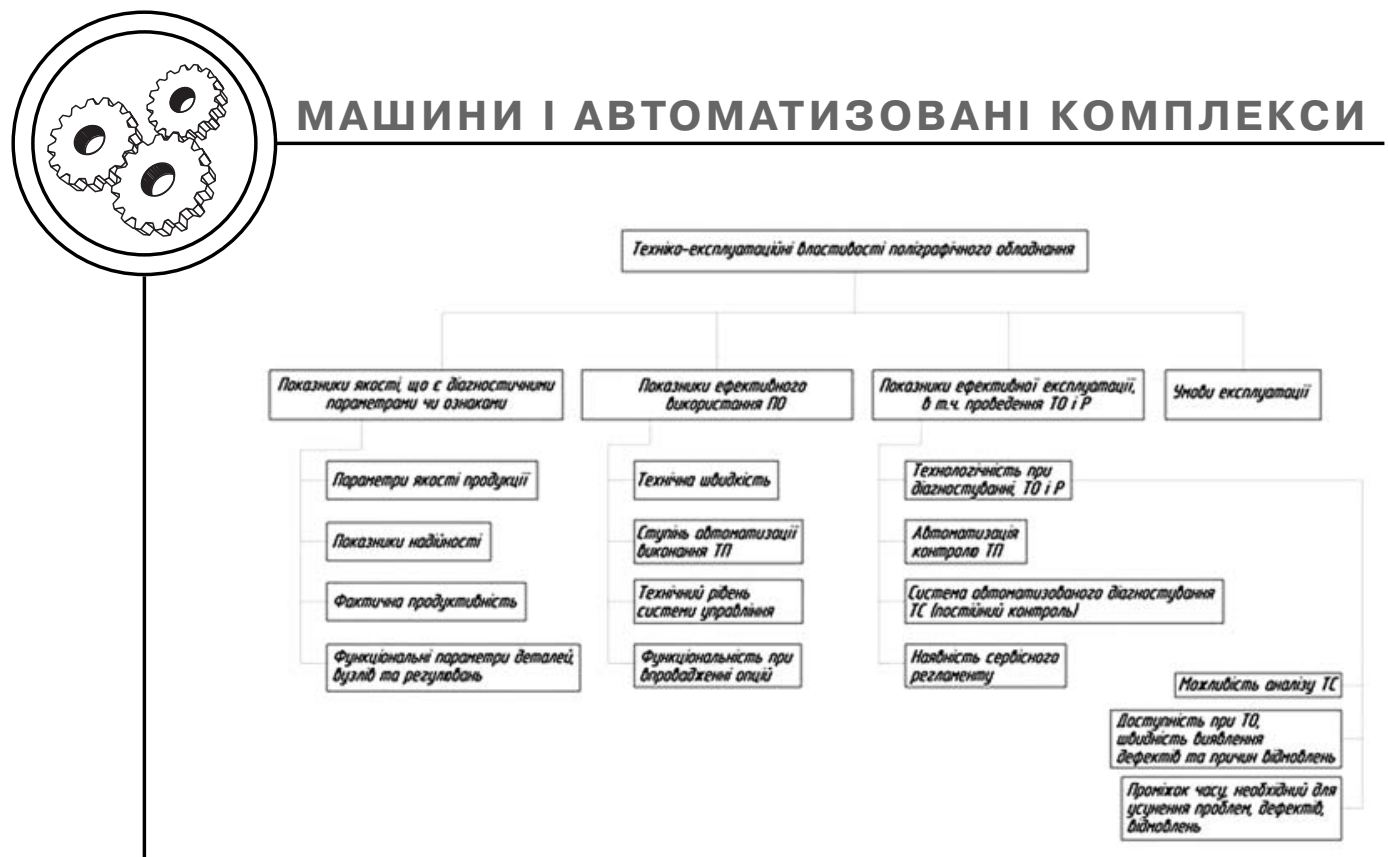

Рис. 3. Техніко-експлуатаційні властивості і показники поліграфічного обладнання

твердженій системі ТО і Р. На рис. 3 представлена схема техніко-експлуатаційних властивостей для поліграфічного обладнання.

2. Для визначення технікоексплуатаційних властивостей складових техпроцесу і конструкції ДА для флексодруку на ГК був проведений аналіз побудови конструкцій апаратів для ма-

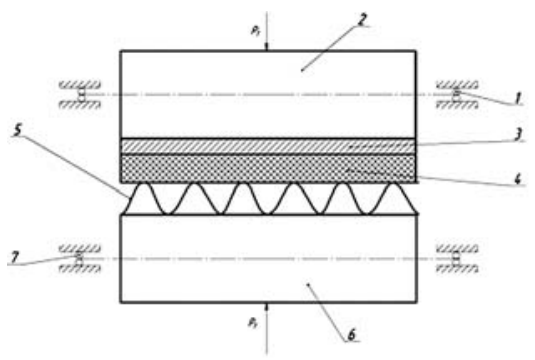

Рис. 4. Узагальнена схема силової взаємодії елементів ФДА:

1 - підшипники формного циліндру; 2 - формний циліндр; 3 - монтажна стрічка; 4 - фотополімерна форма; 5 - ГК; 6 - друкарський циліндр; 7 - підшипниковий вузол друкарського циліндру шин різного технічного рівня, а також проведено попереднє експериментальне визначення фізико-механічних характеристик гофрокартону, формної системи і друкарської пари, які суттєво можуть впливати на механіку дукарського контакту. Забезпечення технологічного тиску (рис. 4) супроводжується деформацією стиснення всіх елементів,що беруть участь у процесі друкування. Необхідне технологічне зусилля створюється за рахунок тиску на нижню частину гофрокартону зі сторони друкарського циліндра шляхом зміни його положення в ексцентричних підшипникових опорах.

Деформація гофрокартону виникає внаслідок площинного стиску аркуша в зоні друку. Гофрокартон - багатошаровий матеріал, який складається 3 послідовно з'єднаних плоского аркушу паперу (лайнера) та гофрованого шару (флютінга) [12]. Головними параметрами, які впливають на фізико-меха- 
нічні характеристики ГК, є крок та довжина хвилі гофру (рис. 5). В залежності від їх значень на погонний метр приходиться від 108 до 560 кількості хвиль. Саме цей параметр суттєво обумовлює опір площинному стиску аркуша та частково гладкість його поверхні, що дуже важливо для якості друку.

Для виготовлення тари в основному використовують гофри типу А - крупний, C - середній, В - мілкий і E - перший мікрогофр. Тому попередні дослідження проводились на зразках три- і п'ятишарового картону з вказаними типами гофрів. При плануванні експерименту були прийняті до уваги вимоги ГОСТ 20681 [13], який регламентує методику проведення цих випробувань для ГК. Були визначенні абсолютні деформації гофрокартону в діапазоні 0,08-0,2 мм в області друкарського тиску 0,05-0,3 мПа, які знаходяться у даному діапазоні. По результатам експерименту були побудовані залежності $p=f\left(f_{\Gamma K}\right)$, що характеризують граничні значення діапазону площинного стиску в залежності від типу та параметрів гоофрокартону. Область тиску відповідала значенням 0,05-0,3 мПа. Структура частини взірців ГК була зруйнована.

Останнім часом спроби стандартизувати вимоги до якості продукції, виготовленої флексодруком призвели до певної класифікації ФПФ та їх установки на ФЦ. Введено поняття формної системи, яку складають ФПФ і монтажна стрічка. В залежності від ступеня деформації при створені тиску друку формні системи аналогічно декелям підрозділяють на жорсткі та м'які $[6,7,11]$. Для друку на листах ГК з гофрами А, С і B застосовують м'які формні системи, що утворюють ФПФ товщиною 3,94-6,35 мм 3 монтажною стрічкою товщиною 0,1-0,2 мм. у цих системах надлишковий тиск компенсується за рахунок деформації шарів товстої форми. Тиск повинен бути невеликим, тому що в іншому випадку будуть мати місце порушення якості відбитку - ефект «пральної дошки», розтискування, ореоли та інше. У зв'язку з тим, що відсутня системна оцінка залежності стиснення ФПФ від площинного стиску було проведено іï експериментальне визначення для форм товщиною 5,5 мм, які використовує ВАТ «Київський КБК» для флексодруку на гофрокартоні типу Т з гофром «С».

Під дією зусилля тиску, який необхідний для якісного друку, всі елементи друкарського апарату деформуються. Це зменшує деформацію форми для забезпечення необхідного технологічного тиску, а також приводить до перепаду тисків вздовж довжини відбитка. Крім того згинальна жорсткість валів також визначає правильні умови роботи зубчатих зчеплень, що пов'язано з забезпеченням їх точності в процесі роботи. Тому жорсткість ДА - важливий показник якості

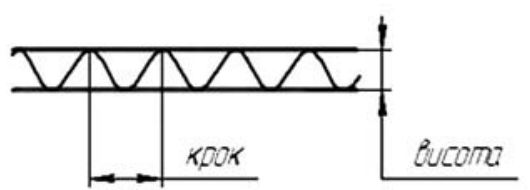

Рис. 5. Параметри гофрокартону 


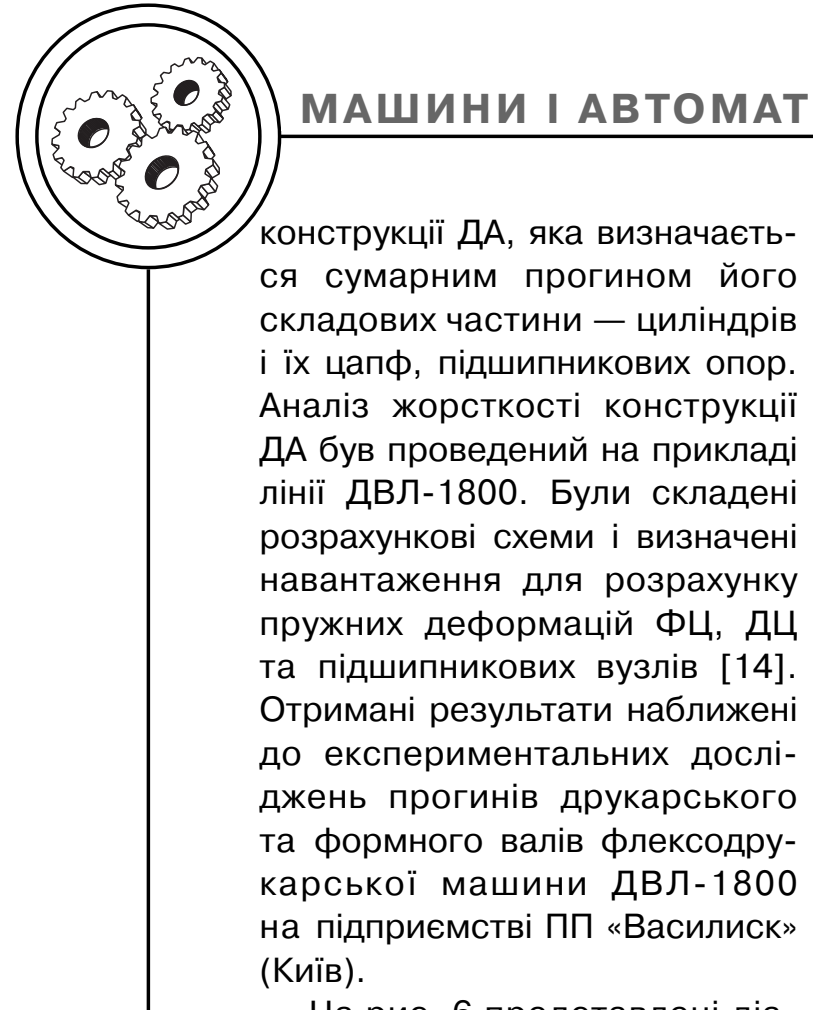

На рис. 6 представлені діаграми залежності p(f), які були отримані при дослідженнях для всіх розглянутих вище елементів. Для якісного друку для конкретного значення технологічного тиску необхідно виконання залежності

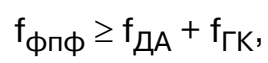

де $\mathrm{f}_{\text {пп }}$ - абсолютна деформація стиснення ФПФ, $\mathrm{f}_{\text {ДА }}-$ сумарна абсолютна деформація ДА, що складається з прогину друкарського і формного циліндрів і радіальної жорсткості їх підшипників, $f_{\ulcorner К}-$ абсолютна деформація стиснення ГК.

3 рис. 6 очевидно, що жорсткість ГК і ФПФ для однакових значень тиску можуть співпадати, а жорсткість ДА складає до 25-30\% жорсткості ФПФ. Тобто залежність (1) виконується не завжди.

3. Наведені результати попередніх досліджень згинальної жорсткості, проаналізовані та виявлені фактори впливу параметрів технологічного процесу і конструкції друкарського апарату на якість продукції дозволили систематизувати експлуатаційні показники якості, які суттєво впливають на механіку друкарського контакту. До них слід віднести - жорсткість і точність ДА і його приводу, деформаційні характеристики при пло-

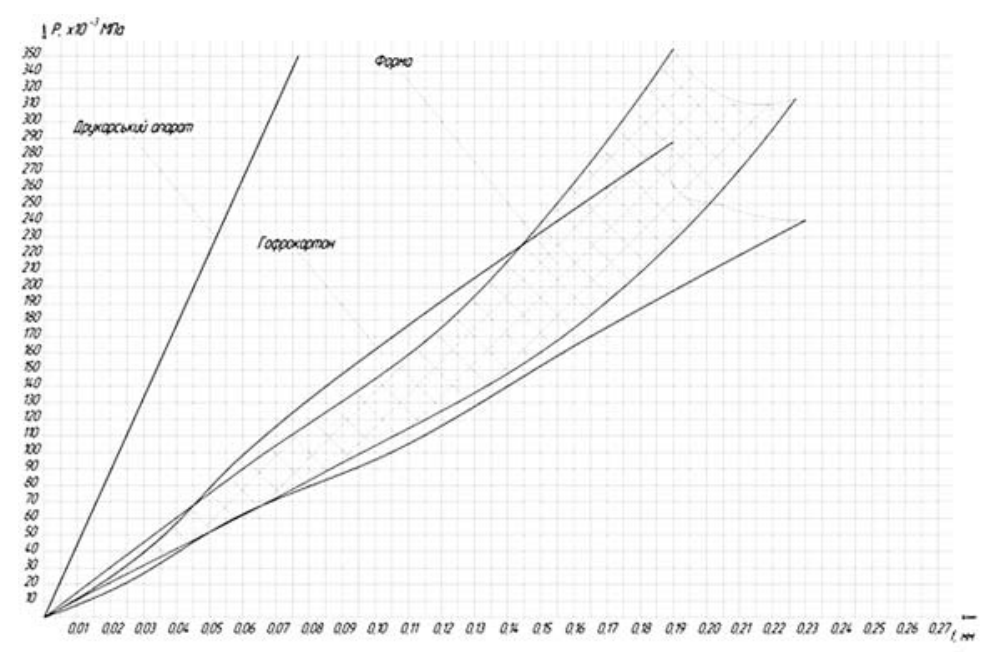

Рис. 6. Жорсткість елементів, що суттєво впливають на якість друкування 


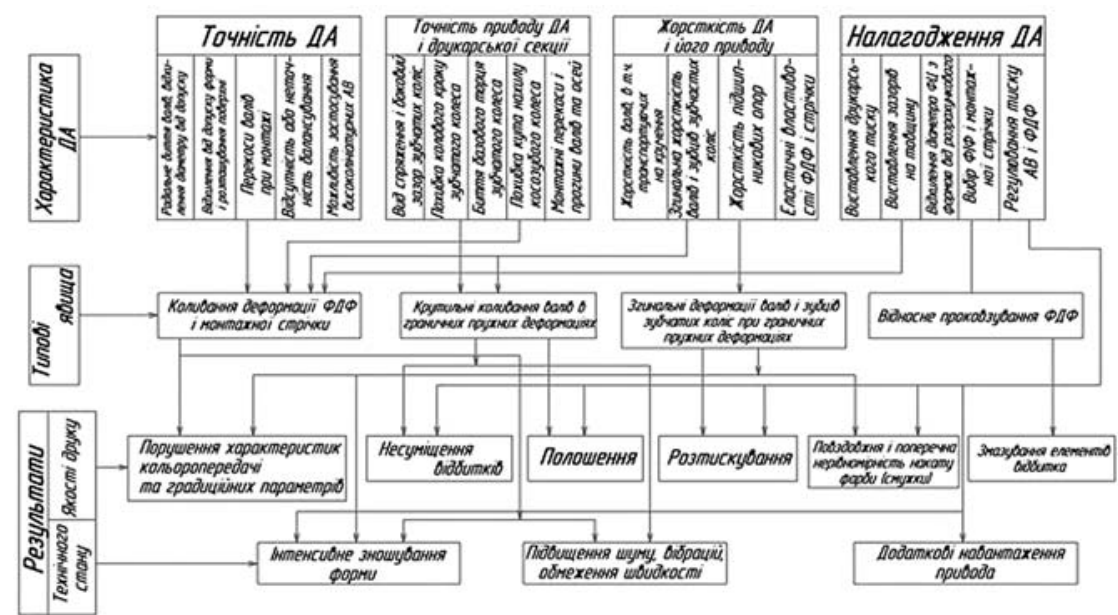

Рис. 7. Систематизація факторів впливу складових конструкції ДА на якість продукції і механіку друкарського контакту

щинному стиску ГК і ФПФ, технічний рівень системи налагодження ДА. Між показниками, їх впливом на якість друку і явища, що виникають при роботі ДА, існує взаємозв'язок, який був виявлений в процесі систематизації і представлений на рис. 7.

\section{Висновки}

1. Розглянуті особливості технологічного процесу і конструкції друкарського апарату для флексодруку на ГК. Проаналізовані стан технічного рівня, схеми і особливості побудови ДА.

2. В діапазоні технологічних навантажень, що рекомендовані для ГК, проведена попередня експериментальна оцінка деформаційних властивостей стиснення тришарового і п'яти- шарового ГК і м'якої ФПФ товщиною 5,5 мм. Проведені розрахунки згинальної жорсткості друкарської пари лінії ДВЛ-1800 в складі формного, друкарського циліндрів і їх підшипникових вузлів.

3. Виявлені і систематизовані фактори впливу на якість друку і механіку друкарського контакту в флексографічних апаратах друку на ГК. До них слід віднести наступні характеристики: згинальну жорсткість циліндрів ДА, деформації стиснення гофрокартону і формних систем; точність ДА та його приводу; технічний рівень системи налагодження ДА.

4. Результати роботи можуть бути використані при подальших дослідженнях механіки друку на ГК флексографічним способом.

1. Звіт World Packaging Organisation 2010 [Електронний ресурс]. - Peжим доступу : http : www.wpo.com. 2. Чехман Я. І. Друкарське устаткування : підручник / Я. І. Чехман, В. Т. Сенькусь, В. П. Дідич, В. О. Босак. - Львів : УАД, 2005. - 468 с. 3. ГОСТ 15467-79. Управление качеством продукции. Основные понятия. Термины и определения. Переиздание - июнь 1986 г. - 
М. : Из-во стандартов, 1987. 4. Дуб Я. І. Деформація друкарського елемента фотополімерної форми / Я. І. Дуб, Г. В. Огірко, М. Ф. Ясінський // Сб. «Поліграфія і видавнича справа». - Львів, 1986. - Вип. 4. - С. 49. 5. Ярема С. М. Флексографія: Обладнання. Технологія: Навч. посібник / Ярема С. М. - К. : Либідь, 1998. - 312 с. 6. Б. Килхенни. Сжимаемость демпферных лент / Брет Килхенни // ФлексоДрук Ревю. — 2000. — № 4. - С. 37. 7. А. Фрейзер-Тауш. Оптимальное соотношение для желаемого результата / Анке Фрейзер-Тауш // ФлексоДрук Ревю. - 2004. - № 2. - С. 22. 8. Шибанов В. В. Поля деборы или релаксация флексографских материалов / В. В. Шибанов, М. К. Гладилович, Г. П. Бузина // ФлексоДрук Ревю. - 2002. № 4. - С. 12. 9. Сорокин Б. А. Флексографская печать / Б. А. Сорокин, О. В. Здан. - М. : МГАП «Мир книги», 1996. - 192 с. 10. Бочкарев С. Печать на гофрокартоне: дефекты и способы их устранения / С. Бочкарев // Флексо Плюс. - 2000 [Електронний ресурс]. - Режим доступу : http : www.publish.ru. 11. Ефремов Н. Печать на гофрокартоне / Н. Ефремов // Гофроиндустрия. - 2004. - № 3(3). - С. 18-24. 12. Шредер В. Л. Упаковка из картона / В. Л. Шредер, С. Ф. Пилипенко. - Киев : Ш85 ИАЦ «Упаковка». - 2004. 560 с. 13. ГОСТ 20681-75 Картон гофрированный. Метод определения сопротивления плоскостному сжатию (FCT). Изменения 1, 2. - 2000 г. - Изво стандартов, 2000. 14. Серпионов Н. Н. Методика технического расчёта на жёсткость печатного узла ротационных машин. (К вопросу о снижении веса.) / Н. Н. Серпионов. - М. : Искусство, 1955. - С. 125-149 (Научные труды МЗПИ. - Вып. ІІ). 